\title{
Investigation of Helminth Infections on Smallholder Farming Beef Cattle at Palm-Cow Integration in East Kalimantan and Riau provinces, Indonesia
}

\author{
E Martindah 1,*, D H Sawitri ${ }^{1}$, Y Sani ${ }^{1}$, D Yulistiani ${ }^{2}$, D A Kusumaningrum ${ }^{2}$, Y \\ Widiawati $^{2}$, D Sisriyeni ${ }^{3}$, S Gloriana ${ }^{4}$, and K McCoascker ${ }^{5}$ \\ ${ }^{1}$ Indonesian Research Centre for Veterinary Science, Indonesian Agency for Agricultural Research and Development, \\ Bogor, Indonesia. \\ ${ }^{2}$ Indonesian Research Institute for Animal Production, Bogor Indonesia \\ ${ }^{3}$ Assessment Institute for Agricultural Technology, Pekanbaru, Riau \\ ${ }^{4}$ Assessment Institute for Agricultural Technology, Samarinda East Kalimantan \\ ${ }^{5}$ Northern Territory Department of Primary Industry and Fisheries, PO Box 1346 Katherine NT 0851, Australia. \\ *Corresponding author. E-mail: emartindah@gmail.com
}

\begin{abstract}
An integrated palm-cow management system has been introduced to increase population and production of beef cattle in Indonesia. The objective of the study was to assess the helminth infections on beef cattle in the palm-cow integration in East Kalimantan and Riau provinces under smallholder farming system. A cross sectional survey was carried out during November - December 2020 to observe diseases occurrence, interview the owner and animal health officer, as well as collected faecal sample of cattle in extensive, intensive and semi-intensive management. The clinical signs during field observation were diarrhoea, cachexia, anorexia and reproductive disturbance. In East Kalimantan, the prevalence of trematode (fasciolosis) in Bali cattle $(65,5 \%)$ raised extensively was higher compared to Brahman cross $(32 \%)$ that raised intensively. Conversely, the prevalence of nematodes in crossbreed was higher than in local breed (28\% vs $10.34 \%)$. In Riau, cattle were kept in semi-intensive indicates that cross breed was more susceptible than local breed to nematode infestation (41.67\% vs $22.73 \%$ ), and to trematodes (Fasciola) (29.17\% vs $18.18 \%$ ). Beef cattle reared in palm cow-integration systems showed minimal cases of infectious diseases. Gastrointestinal parasites are potentially affected on ingested nutrient loss and metabolic disorder led to poor productivity and reproductivity of beef cattle.
\end{abstract}

Keywords: beef cattle, helminth infection, integration, palm-cow, small-holders farm

\section{INTRODUCTION}

Oil palm and cattle integration system is one approach to increase palm productivity as well as increasing an additional value of oil palm plantation for farmer's income. It remains a significant strategy to accelerate beef production in Indonesia. Increases of population, income and urbanization in Indonesia caused an increased demand for beef. Many programs have been conducted by Government of Indonesia, such as importing frozen beef and increased domestic cattle population by importing beef cattle breed stock or through program securing productive cows.
The Ministry of Agriculture has prepared a strategy to achieve beef self-sufficiency in 2026 , by providing and utilizing land for integration, as well as adding imported breeding stock [1]. Policy within Indonesia is now focused on increasing the production efficiency and size of the breeder herd to increase both female and beef output. However, challenges remain as smallholder production of beef in Indonesia accounts for over $90 \%$ of domestic supply [2] and therefore increasing herd size is constrained by land availability, low breeding herd productivity, and a scarcity of economically assessable feed in certain regions. The main sources of cheap feed for cows and calves are grasses and other 
feeds along roadsides and other uncultivated areas, crop residues, by-products and fodder crops.

Oil palm plantation are underutilized land resource, provide potential feed sources including understory herbage [3], green palm fronds which are routinely pruned can be used as a source fibre as grass replacement but often unused and by-products such as palm kernel cake (PKC) and solid ex-decanter. Under palm-cow integration, various production systems were practiced by smallholder farmers from extensive (where cattle reside, feed and breed within the plantation) to intensive (where cattle are permanently contained within pens located within the farming communities). In between these two, many semi-intensive cattle production systems are observable where cattle are held in pens for varying time periods and grazed within the plantation. According to Kusnadi [4], the palm livestock integration system can expand and strengthen farmers' sources of income while reducing the risk of business failure. However, studies related to cattle health reared with an integrated palm-livestock management system have not been widely reported. Helminth's infection is the most sub clinically important diseases of cattle which are often ignored resulting in heavy economic loss. Martin \& Meek [5] stated that the economic losses due to sub-clinical problems in population are significantly higher than clinical problems in individual animals. Economic losses due to fasciolosis in Indonesia had been studied in Banyumas Ex-resident [6], and reported that the factors of infection rate, body weight, age and origin of cattle greatly affect the level of economic loss by $62.5 \%$. The objective of the study was to assess the helminth infections of beef cattle in the palm-cow integration in East Kalimantan and Riau provinces under smallholder farming system.

\section{MATERIAL AND METHODS}

\subsection{Study area and faecal samples collection}

The study areas were in East Kalimantan dan Riau Provinces. Location in East Kalimantan Province, was in Longikis, Paser district and in Babulu, Penajam Paser Utara district. Geographically Paser district is located at $1,6^{\circ} 01^{`} 00^{\prime \prime}-02^{\circ} 27^{`} 20^{\prime}$ " LS and $115^{\circ} 36^{`} 14^{\prime \prime}-118$ - 57 35" East Longitude, while Penajam Paser Utara district at $01^{\circ} 48^{\circ} 29^{\prime \prime}-01^{\circ} 36^{\circ} 37^{\prime \prime} \mathrm{LS}$ and $116^{\circ}$ $19^{\prime} 30^{\prime}$ - $116^{\circ}$ 56 35" East Longitude. East Kalimantan province belongs to the tropical humid climates with annual average rainfall is $222.9 \mathrm{~mm} / \mathrm{year}$, and annual average temperatures of $25^{\circ} \mathrm{C}$. In Riau Province the study was carried out in Tapung, Kampar district. The Kampar district lies between $1^{\circ} 00^{\prime} 40$ "north latitude to $0^{\circ} 27^{\prime} 00^{\prime \prime}$ south latitude and $100^{\circ} 28^{\prime} 30$ "- $101^{\circ} 14^{\prime} 30^{\prime \prime}$ east longitude. The average air temperature of Riau is $25.9^{\circ} \mathrm{C}$ with maximum temperatures reaching $34.4^{\circ} \mathrm{C}$ and minimum temperatures reach $20.1^{\circ} \mathrm{C}$. The average rainfall in Riau Province is between 2,000 - 3,000 mm / year.

A cross sectional survey was carried out during November-December 2020 to observe diseases occurrence, interview the owner and animal health officer, as well as collected faecal samples of cattle. In total of 100 faecal samples from 39 farmers/herds were collected. The total number of faecal samples from East Kalimantan was 54 samples, consist of 29 faecal sample of Bali cattle which were kept extensively; and 25 faecal samples of Brahman Cross cattle reared intensively. The total number of faecal samples from Riau province was 46 samples collected from local cattle (Bali and Ongole) and cross breed (Limosin, Brahman) reared semi intensively by 15 farmers in Tapung, Kampar district. Faecal samples were collected either directly from the rectum using plastic gloves or when freshly passed. Sample was placed individually in a plastic bag then samples were kept in a cooler box and immediately kept in a refrigerator at $4^{\circ} \mathrm{C}$ until analysed.

\subsection{Methods}

\subsubsection{Examination Nematode Eggs}

Quantitative faecal examinations of nematode eggs are performed with modification of Whitlock method $[7,8]$. Briefly, three grams of each faeces sample were soaked in $17 \mathrm{ml}$ of water and left for a few minutes for soften and stirred homogeneously. Then add $40 \mathrm{~mL}$ of saturated sodium chloride $(\mathrm{NaCl}$, specific gravity $=$ 1.200) mix homogenously and put into the 'whitlock chamber' counting room with modification pasteur pipette $(0.5 \mathrm{~mL} / \mathrm{room})$ and then left for $2-5$ minutes for floating the egg. The eggs were identified under a microscope at $40 \times$ magnifications, and counting on the basis of morphology (shape and size). Nematode eggs were counted (in the counting chamber) and the number was multiplied by 40 . The number of eggs was counted in units of egg per gram (EPG).

\subsubsection{Examination Trematode Eggs}

Faecal samples were examined by sedimentation techniques for the presence of trematode eggs as described by [9]. Three grams of the faecal sample was homogenized with $17 \mathrm{~mL}$ of water and left for 2-4 hours 
at room temperature. The solution of Tween-80 was added and then homogenized by a magnetic stirrer for 5 min. The faecal solution was filtered using the size of filter $341 \mu \mathrm{m}, 200 \mu \mathrm{m}$ and $150 \mu \mathrm{m}$. The filtrate is collected in a beaker (cone tube) then added water to a volume of $250 \mathrm{~mL}$ and allowed to settle for 3 minutes. The stopper (plug) is slowly inserted into the cone tube in an upright position with a little pressure, then the supernatant or upper liquid is removed. Again, the water is added to the sediment. This deposition process is carried out about 5 times until the supernatant is clear and then removed. The remaining sediment is placed on a clean and dry petri dish, then $1 \%$ methylene blue dye is added and emulsified. Trematode eggs (Paramphistomum spp and Faciola gigantica) was indentified under a stereomicroscope with 10X magnification based on the morphogical characteristic of the eggs. Paramphistomum spp eggs looked bluishgrey in colour, while Faciola.gigantica eggs appeared in golden-yellow shiny colour [10].

\section{RESULTS AND DISCUSSION}

\subsection{Prevalence of Gastrointestinal Nematodes and Trematode}

The results of faecal samples examination of local and Cross Breed cattle in East Kalimantan and Riau Provinces are presented in Table 1 and Table 2. In general, samples from East Kalimantan showed that the prevalence of trematode infestation was higher than nematode infestation. The infection rate of trematode, Fasciola gigantica, was 50\% (CI 95\%; 37.1\%-62.9\%) and Paramphistomum spp was 63\% (CI 95\%; 49.6\%$74.6 \%$ ), while nematode (strongyle) was found $18.5 \%$ (CI 95\%; 10.4\%- 30.8\%). Multiple infection of both Paramphistomum spp and Fasiola gigantica were found in 22 of the 54 samples. This result was in line with study by Rinca, et al., [11] that cattle were experience with multiple infection of both Fasciola spp. and Paramphistomum spp. However, the rate of infection in this study $40.74 \%$ (CI 95\%; 28.7\%-54\%) was lower compared to the previous study $(50 \%)$ by Rinca, et al. [11]. The prevalence of GI trematode (fasciolosis) showed a relatively higher occurrence in local breed $(65.5 \%)$ which were reared extensively, compared to cross breed $(32 \%)$ which were reared intensively. In contrast, relatively higher nematode positive animals were recorded in cross breed $(28 \%)$ than local breed (10.3\%). Moreover, beef cattle that negative from helminthiasis were $20,69 \%$ and $12 \%$ in local and cross breeds respectively. This current study is in contrary to
Zekarias et al. [12] who reported no significant effect of breed and management systems on the occurrence of gastro-intestinal nematodes.

The examination of 46 faecal samples from local breeds (Bali, Ongole) and cross breeds (Brahman, Simental) which were reared semi-intensively at Tapung, Kampar district, Riau is shown in Table 2. The results revealed that out of the 46 samples of faeces examined, 32.61\% (CI 95\%; 20.9\%-47\%) were infected with nematode, while from the genera trematode, $23.91 \%(11 / 46)$ samples were infected with $F$. gigantica and $15.22 \%(7 / 46)$ were infected paramphistomum spp. Only two $(4.35 \%)$ crosses and locals were positively infected with a mixture of Fasciola gigantica and Paramphistomum spp. However, there were $36.96 \%$ cattle that free from helminths infection, those were $40,91 \%$ of local breed and $33,33 \%$ of cross breed.

Higher infection of nematodes was recorded in cross breed than local breed $(41.67 \%$ vs. $22.73 \%$ ), it also found that cross breed was more susceptible to $F$. gigantica compare to local breed $(29.17 \%$ vs. $18.18 \%)$. Cattle reared by smallholder farmers in the palm cow integration showed that the highest rate of fasciolosis infection $(65.5 \%)$ was recorded in samples from extensively reared local breeds, followed by intensively reared cross breeds while the lowest $(23.91 \%)$ in semiintensively reared mixed breeds. The finding was in line with Khan and Maqbool [13] who reported the rate of fasciolosis infection varied under different management conditions. However, he found that fasciolosis infection rate of cattle at livestock farms $(17.5 \%)$ were lower than in the present study $50 \%$ and $23,91 \%$ in East Kalimantan and Riau province respectively. This finding indicated that the infection of fasciolosis was differ among the region. In addition, cattle in extensive systems directly eat grass while cattle reared in intensive and semi-intensive systems whose feed does not go through withering have a probability of getting fasciola infestation [14]. The incidence of fasciolosis is influenced by two factors, temperature and moisture, as they affect the hatching of fasciola egg, the viability of cercariae and population of snails [15] (Walker et al., 2008). On the other hand, there is a habit of making sewage drains directly into the grass area which causes the continuing fasciola life cycle and spread to other livestock [14, 16]. Trematodosis such as Fasciolosis and paramphistomosis are chronic and subclinical, and difficult to be recognize, that lead farmers do not aware how to prevent the disease [17]. 
Table 1. Prevalence of GI nematode and trematode infection of beef cattle reared on extensive and intensive system in the district of Penajem Paser Utara and Paser, East Kalimantan Province

\begin{tabular}{|c|c|c|c|c|c|c|}
\hline \multirow[b]{2}{*}{ Breed } & \multirow[b]{2}{*}{$\begin{array}{l}\text { No. } \\
\text { Examined }\end{array}$} & \multirow{2}{*}{$\begin{array}{c}\text { Nematoda (\%) } \\
\text { (Strongyle) }\end{array}$} & \multicolumn{3}{|c|}{ Trematoda (\%) } & \multirow{2}{*}{$\begin{array}{l}\text { Negative } \\
\text { Nematoda and } \\
\text { Trematoda }\end{array}$} \\
\hline & & & F.gigantica & $\begin{array}{c}\text { Paramphistomum } \\
\text { spp }\end{array}$ & $\begin{array}{c}\text { (Fasc+ } \\
\text { Paramp) }\end{array}$ & \\
\hline $\begin{array}{c}\text { Local } \\
\text { (extensive) }\end{array}$ & 29 & 3 (10.3\%) & 19 (65.5\%) & $18(62 \%)$ & 15 (51.7\%) & 6 (20.69\%) \\
\hline $\begin{array}{c}\text { Cross } \\
\text { (Intensive) }\end{array}$ & 25 & 7 (28\%) & $8(32 \%)$ & 16 (64\%) & 7 (24.1\%) & $3(12 \%)$ \\
\hline Total & 54 & $\begin{array}{c}10 \text { (18.50\%) } \\
\text { (Cl 95\%; } \\
10.4 \%-30.8 \%)\end{array}$ & $\begin{array}{c}27(50 \%) \\
(\mathrm{C} 195 \% ; \\
37.1 \%-62.9 \%)\end{array}$ & $\begin{array}{c}34 \text { (63\%) } \\
\text { (Cl 95\%; } \\
49.6 \%-74.6 \%)\end{array}$ & $\begin{array}{c}22 \text { (40.70\%) } \\
\text { (Cl 95\%; } \\
28.7 \%-54 \%)\end{array}$ & $\begin{array}{c}9(16.67 \%) \\
\text { (Cl 95\%; 9.02\%- } \\
28.74 \%)\end{array}$ \\
\hline
\end{tabular}

Table 2. Prevalence of GI nematode and tematode infection of beef cattle reared on semi-intensive system at Tapung, Kampar district, Riau Province

\begin{tabular}{|c|c|c|c|c|c|c|}
\hline \multirow[b]{2}{*}{ Breed } & \multirow[b]{2}{*}{$\begin{array}{l}\text { No. } \\
\text { Examined }\end{array}$} & \multirow{2}{*}{$\begin{array}{c}\text { Nematoda } \\
\text { (\%) } \\
\text { (Strongyle) }\end{array}$} & \multicolumn{3}{|c|}{ Trematoda (\%) } & \multirow{2}{*}{$\begin{array}{l}\text { Negative } \\
\text { Nematoda and } \\
\text { Trematoda }\end{array}$} \\
\hline & & & F. gigantica & $\begin{array}{c}\text { Paramphistomum } \\
\text { spp }\end{array}$ & $\begin{array}{l}\text { (Fasc+ } \\
\text { Paramp) }\end{array}$ & \\
\hline $\begin{array}{l}\text { Local breed *) } \\
\text { Ongole, bali }\end{array}$ & 22 & 5 (22.73\%) & 4 (18.18\%) & 4 (18.18\%) & $1(4.55 \%)$ & $9(40,91 \%)$ \\
\hline Cross breed $\left.^{\star}\right)$ & 24 & 10 (41.67\%) & 7 (29.17\%) & $3(12.50 \%)$ & $1(4.17 \%)$ & 8 (33.33\%) \\
\hline Total & 46 & $\begin{array}{c}15 \text { (32.61\%) } \\
\text { (Cl 95\%; } \\
20.9 \%-47 \%)\end{array}$ & $\begin{array}{c}\text { 11(23.91\%) } \\
(\mathrm{C} 195 \% ; \\
13.9 \%-37.9 \%)\end{array}$ & $\begin{array}{c}7 \text { (15.22\%) } \\
\text { (Cl 95\%; } \\
7.6 \%-28.2 \%)\end{array}$ & $\begin{array}{c}2 \text { (4.35\%) } \\
\text { (Cl 95\%; } \\
1.2 \%-14.5 \%)\end{array}$ & $\begin{array}{c}17 \text { (36.96\%) } \\
\text { (Cl 95\%; } \\
24.52 \%-1.40 \%)\end{array}$ \\
\hline
\end{tabular}

Note: *) All cattle reared semi-intensively

\subsection{Animal Health Status and diseases occurrence}

The general animal health status observed in East Kalimantan and Riau. Table 3 showing that 40 beef cattle in East Kalimantan located in Paser and Panajem Paser Utara had been observed for their health status. The beef cattle were between 8 months and 6 years old with body score condition (BSC) between $<2$ and 4 . Clinical signs were noted as anorexia, cachexia, diarrhoea, repeat breeding and silent heat. Since 15 out of 40 beef cattle $(37.5 \%)$ were having $\mathrm{BSC} \leq 2$, it requires further investigation and improvement. In Riau, 21 of 32 cattle $(65.62 \%)$ were having $\mathrm{BSC} \leq 2$ and clinical signs noted similar to East Kalimantan. Low BSC value appear to related to the clinical signs noted from these cattle such as anorexia and cachexia. These clinical signs seem to be due to parasitic diseases, metabolic disorder and/or under-nutrition. However, study in Ethiopia by Zekaries et al. [12] found that BSC of the cattle did not significant different with the prevalence of the parasites. This agrees with previous report of previous studies $[18,19]$ who described that the deterioration in body condition of animals might be due to malnutrition and other concurrent diseases. It requires further investigation and improvement for these cattle, particular laboratory analysis should be undertaken such as metabolic diseases and reproduction failures.

The overall BSC value is shown in Table 3 Forty cattle of East Kalimantan were measured for BSC showing that 4 Ongole cattle, 9 Brahman cross and 2 others with $\mathrm{BSC} \leq 2$. While 1 Bali cattle, 19 Brahman cross and 1 other of 32 cattle in Riau showing $\mathrm{BSC} \leq 2$. It is appeared that Brahman cattle were more sensitive than local cattle when introduced to the palm-cow farming system. 
Table 3. The body score condition (BSC) of beef cattle in Province of East Kalimantan and Riau.

\begin{tabular}{|c|c|c|c|c|c|c|c|c|c|}
\hline \multirow{2}{*}{ No. } & \multirow{2}{*}{ Provinces } & \multirow{2}{*}{$\begin{array}{l}\text { Number of } \\
\text { Animals }(n)\end{array}$} & \multirow{2}{*}{ Breeds } & \multirow{2}{*}{$\mathrm{N}$} & \multirow{2}{*}{$\begin{array}{c}\text { Ages } \\
\text { (month/years) }\end{array}$} & \multicolumn{4}{|c|}{$\mathrm{BSC}$} \\
\hline & & & & & & 1 & 2 & 3 & 4 \\
\hline \multirow{4}{*}{1.} & \multirow{4}{*}{ East Kalimantan } & \multirow{4}{*}{40} & Bali & - & \multirow{4}{*}{8 month -6 year } & - & - & - & - \\
\hline & & & $\mathrm{PO}$ & 16 & & - & 4 & 10 & 2 \\
\hline & & & $B X$ & 17 & & 2 & 7 & 8 & - \\
\hline & & & Others & 7 & & - & 2 & 5 & - \\
\hline \multirow{5}{*}{2.} & \multirow{4}{*}{ Riau } & \multirow{4}{*}{32} & Bali & 3 & \multirow{4}{*}{$1,2-8$} & - & 1 & 1 & 1 \\
\hline & & & $\mathrm{PO}$ & - & & - & - & - & - \\
\hline & & & $B X$ & 27 & & 9 & 10 & 7 & 1 \\
\hline & & & Others & 2 & & - & 1 & 1 & - \\
\hline & Total & 72 & & 72 & & 11 & 25 & 32 & 4 \\
\hline
\end{tabular}

\section{CONCLUSION}

Beef cattle reared in palm cow-integration systems showed minimal cases of infectious diseases. The clinical signs during field observation were diarrhoea, cachexia, anorexia and reproductive disturbance. These clinical signs seem to be due to parasitic diseases, metabolic disorder and/or mal-nutrition. Gastrointestinal parasites are potentially affected on ingested nutrient loss and metabolic disorder led to poor productivity and reproductivity of beef cattle. It is appeared that cross breed cattle were more sensitive than local cattle when introduced to the palm-cow farming systems.

\section{AUTHORS' CONTRIBUTIONS}

All authors contributed equally, as a main author, in writing the manuscript.

\section{ACKNOWLEDGMENT}

This study was conducted by the join research funding between AARD and ACIAR, project number: LS/2015/048 'Improving smallholder beef supply and livelihoods through cattle-palm system integration in Indonesia (2018-2020).

\section{REFERENCES}

[1] Handi. 2020. Jumlah Populasi Sapi Potong JawaTimur Terbanyak di Indonesia. Berita Daerah.Co.Id.

https://www.beritadaerah.co.id/2020/09/22/jumla h-populasi-sapi-potong-jawa-timur-terbanyak-diindonesia.

[2] Badan Pusat statistik 2020. Peternakan dalam angka, Badan Pusat Statistik, Jakarta. Indonesia.

[3] Purwantari, N., Tiesnamurti, B., \& Adinata, Y. 2015. Ketersediaan sumber hijauan di bawah perkebunan kelapa sawit untuk penggembalaan sapi. Wartazoa, 25(1), 47-54 http://dx.doi.org/10.14334/wartazoa.v25i1.1128 $\% 0$ AKetersediaan

[4] Kusnadi, U. 2008. Inovasi Teknologi Peternakan dalam Sistem Integrasi Tanaman Ternak untuk Menunjang Swasembada Daging Sapi. Naskah Orasi Profesor Riset, Disampaikan pada tanggal 25 Juni 2007. Pusat Penelitian dan Pengembangan Peternakan, Bogor.

[5] Martin S.W., Meek A.H. 1994. Veterinary Epidemiology: Principle and methods (2nd ed.). Iowa State University Press.

[6] Munadi, M. 2011. 'Tingkat Infeksi Cacing Hati Kaitannya dengan Kerugian Ekonomi Sapi Potong yang Disembelih di Rumah Potong 
Hewan Wilayah Eks-Kresidenan Banyumas', Jurnal Agripet, 11(1), pp. 45-50. doi: 10.17969/agripet.v11i1.654.

[7] Whitlock H.V. 1948. Some modifications of the McMaster worm egg-counting method and apparatus. J. Counc. Sci. Ind. Res. 21:177-180.

[8] Maff (Ed.), 1986. Fisheries and Food, ReferenceBook, Manual of Veterinary Parasitological Laboratory Techniques, Ministry of Agriculture, HMSO, London, UK.

[9] Suhardono, Robert, J. A., Copeman, D. B., \& Kosasih, Z. 1998. Optimasi prosedur untuk penghitungan telur cacing hati, Fasciola gigantica, dalam feses sapi. Prosiding Seminar Hasil Hasil Penelitian Veteriner, 173-182.

[10] Hambal, M., Ayuni, R., Vanda, H., Amiruddin, A., \& Athaillah, F. 2020. Occurrence of Fasciola gigantica and Paramphistomum spp Infection in Aceh Cattle. E3S Web of Conferences, 151, 1-4. https://doi.org/10.1051/e3sconf/202015101025.

[11] Rinca, K. F., Prastowo, J., Widodo, D. P., and Nugraheni, Y. R. 2019. Trematodiasis occurrence in cattle along the Progo River, Yogyakarta, Indonesia. Veterinary World, 12(4), 593-597.

https://doi.org/10.14202/vetworld.2019.593-597

[12] T. Zekarias, A. Ashebo and T. Tafese. 2020. Prevalence and Identification of Gastrointestinal Nematodes in Bovine in and Around Hawassa, Ethiopia. Acta Parasitologica Globalis 11 (1): 25 32. DOI: $10.5829 /$ idosi.apg.2020.25.32

[13] Khan U.J. and Maqbool A. 2012. Prevalence of Fasciolosis in Cattle Under Different
Managemental Conditions in Punjab. Pakistan J. Zool., vol. 44 (5), pp. 1193-1196, 2012.

[14] Awaludin, A., Nugraheni, Y. R., and Muhamad, N. 2020. Derajat Infeksi Fasciola Sp. Pada Sapi Perah Periode Laktasi. E-Prosiding Seminar Nasional Ilmu Peternakan Terapan, September, 92-96.

https://doi.org/10.25047/proc.anim.sci.2020.13

[15] Walker SM, Makundi AE, Namuba FV, Kassuku AA, Keyyu J, Hoey EM, Prodohl, P, Stothard JR and Trudgett A. 2008. The distribution of Fasciola hepatica and Fasciola gigantica within southern Tanzania constraints associated with the intermediate host. Parasitology, 135: 495-503.

[16] Ramadhan, M. E., Suharyati, S., \& Santosa, P. E. 2018. Prevalensi Cacing Saluran Pencernaan pada Sapi Bali di Kecamatan Candipuro Kabupaten Lampung Selatan. Jurnal Riset Dan Inovasi Peternakan, 2(3), 1-8.

[17] Martindah, E. et al. 2005. 'Improvement of Public Awarness on Fasciolosis as Zoonosis Disease', Wartazoa, 15(3), pp. 143-154.

[18] Regassa, F., T. Sori, R. Dhuguma and Y. Kiros, 2006. Epidemiology of Gastrointestinal Parasites of Ruminants in Western Oromia, Ethiopia. Int. J. Appl.Res. Vet. Med., 4: 51-57.

[19] Hailu, D., A. Cherenet, Y. Moti and T. Tadele, 2011. Gastrointestinal Helminth Infections in Small-scale Dairy Cattle Farms of Jimma Town, Ethiopia. thiopian J. Appl. Sci. Techn., 2: 45. 